\title{
Business Management Training In Bank Bakti Haji Malang
}

\author{
Author \\ Tri Cicik Wijayanti \\ Correspondence \\ Universitas Muhammadyah Gresik \\ Email : tricicikwijayanti@yahoo.com
}

\begin{abstract}
Negotiations and teamwork are needed by anyone. A manager is expected to be able to suggest himself as an entrepreneur, the role of the problem solver, the role as the allocation of resources and the role of the final decision is the role of the negotiator. The role of the negotiator is necessary when dealing with outsiders in terms of determining cooperation or when the organization is confronted with conflicts of interest internally or otherwise. Negotiators must know examples, for example, when we are going to market the product. Follow-up from community service on extracting the potential of human resources to process the potential of human resources in terms of negotiating and team building can increase the added value of these human resources, which in turn can increase the income of employees, enthusiasm for work.
\end{abstract}

Keywords: communication, team building, and negotiation.

Received: 15 Januari 2020. Accepted: 20 Januari 2020.

\section{Introduction}

The Islamic People's Financing Bank Bhakti Haji Malang is one of the financial institutions managed under the Sharia system and has been established since 1996. The existence of the Islamic People's Financing Bank is supported by business facilities in the form of a Head Office located on Jl. Suropati 137 A Kec. Bululawang Malang Regency and supported by two sub-cash offices are in the District of Pakisaji Malang Regency. The basic idea of establishing this Islamic bank is to help improve the quality of the socialeconomic life of rural communities especially those with low incomes and provide an opportunity for every Muslim to come together to create a strong economy.

The ability of the Bhakti Haji Malang to adapt to various changes and the increasingly complex competition will be largely determined by its human resources. The availability of quality human resources who have the ability and good work performance will support the performance of an organization is facing competition with other work organizations. Therefore, today many companies tend to compete with each other to get superior human resources and employ in such a way that the company can face changes and competition.

An example of the emergence of this phenomenon due to progress and changes in the world of work is in the field of Banking in which will be run by Human Resources. In an organization there are individuals. These individuals have the performance or performance of each to achieve effectiveness. The effectiveness itself will affect the effectiveness of the organization. According to Gibson, Ivancevich, Donnelly, and Marwansyah (2012) looked at the concept of organizational effectiveness from three perspectives, namely individual effectiveness, group effectiveness, and organizational effectiveness, therefore these three things are related to one another. Individuals in a group must indeed show the best performance in carrying out their work, this is included in the realm of individual effectiveness, only the fact that individuals within the organization rarely work alone but cooperate with other people (groups). So, in addition to the view of individual effectiveness, there is also a view of effectiveness in terms of groups.

On the results of interviews with the Manager, there is information that there are still 
some employees who are less concerned about their work or with problems in the division, so the supervisor or department head must provide coaching, even some members are less concerned. Furthermore, the results of the questionnaire found that aspects of the team function, skill and Organizational Culture and strengthened by interviews. Communication, good skills are needed by employees, including communication that occurs between employees still often misunderstandings between one another. This if it happens continuously it will result in a problem in the work environment, especially in the implementation of work. With this, good communication or also skill can the company's goals be achieved effectively.

The importance of communication between individuals in the work for the achievement of effectiveness, then ideally every individual in the group can understand how communication must be owned and how to build effective work teams in the division so that it can be managed optimally. Based on the background of the above problems it can be concluded that the skills, negotiations, the the the cooperation of The Islamic People's Financing Bank Bhakti Haji Malang which is intertwined are not going well so that it affects the performance of PT. The Islamic People's Financing Bank Bhakti Haji Malang, this has caused some employees to be less able to adapt well due to gaps in ability, cooperation, and others. Communication is also quite good but not synergized, there is competition in achieving individual targets, and lack of cooperation in the delegation of tasks such as in the division of labor accompanying and others.

On some of the reasons above, the analysis of training needs becomes important and needs to be carried out at the Islamic People's Financing Bank Bhakti Haji Malang to support the performance of employees, so that the formation of an effective team can improve performance more optimally and have a positive impact on PT. Syariah Bhakti Haji People's Financing Bank of Malang itself.

The purpose of this community activity is to find out or explore the potential of human resources and provide training after a survey which is a weakness. Negotiation is needed by anyone. A manager is expected to be able to suggest himself as an entrepreneur, the role of the problem solver, the role as the allocation of resources and the role of the final decision is the role of the negotiator. The role of the negotiator is necessary when dealing with outsiders in terms of determining cooperation or when the organization is confronted with conflicts of interest or other internal interests. Negotiators must know.

\section{Method}

The manufacturing and development phase consists of:

1. A preliminary survey includes:

- Introduction (local officials team)

- Explanation of the purpose of the activity

- Determination of the planned place, time, schedule and material presented

2. Preliminary survey discussions include:

- The results of the conversation with

- Time Allocation

- Lecture material

3. Coaching and counseling I include:

- Submission of material

- Discussion

- Evaluation

4. Coaching and Counseling II include:

- Guidance in connection with field activities

- Solving problems encountered in the field

5. Evaluations include:

Evaluation is done after the practical activities carried out on employees. The evaluation technique is by identifying the number of participants and giving direction. Besides, the evaluation is done by checking how many employees get their customers (Raco, 2010).

\section{Results and Discussion}

Training evaluation is needed to see whether the training objectives have been achieved or not. Training evaluation refers to the process of confirming that someone has achieved competence. Besides, evaluations are needed to improve future programs and replace previously ineffective programs and find out how to start those programs (Fitria, 2010).

Kirkpatrick (1994) revealed that evaluation is needed to determine the effectiveness of a training program, not just to compare the ability of participants before and after training. Kirkpatrick divides the evaluation into four stages, namely: 


\section{a. Phase I: Reaction (Reaction Level)}

At this stage assessing the reaction of the training participants in the form of feelings, thoughts, and desires about the implementation of the training, resource persons and training environment. The results of the evaluation at this stage are input specifically for the facilitator and the training organizer. Various methods can be used at this stage, both qualitative and quantitative.

\section{b. Phase II: Learning (Learning Level)}

This stage measures the learning process in training which is a transfer of learning. Assessment includes the knowledge, skills, and attitudes of participants before and after the training. The results of the assessment become notes for the facilitator, so actions can be taken to increase the capacity of the facilitator or replace them with others.

c. Stage III: Behavior (Behavior Level)

Evaluating at this stage should be able to allocate time to determine the change in behavior. Likewise, an assessment of the behavior of the participants before the training is needed. If there is no change in behavior at this stage, there will be no real outcome from the training. But that does not mean the training is not successful, because at this stage it is related to the next stage.

d. Stage IV: Results (Result Level)

This stage aims to measure the impact or the outcome of training. At this stage also time allocation is needed in its implementation. If there may be pre-training data on the targets to be achieved as a result after the training, the achievements will be compared in the evaluation of this stage.

\section{Conclusion}

1. Forming, At this stage group members conduct an orientation to get to know each other and learn to behave in groups that tend to be polite with other members and be obedient to the group leader.

2. Storming, This stage is often characterized by conflicts that occur between group members. Opposition regarding procedures can cause dissatisfaction and violence.

3. Norming, At this stage, the group begins to appear cohesive, conflicts begin to decrease and trust in the group increases.

4. Performing, the group is mature and knows how to behave, so that they can focus and complete the task. The group prioritizes the performance generated through joint decision making and collaboration.

\section{References}

Fitria, M. (2010). Handout Psikodiagnostika Observasi dan Wawancara (Tidak dipublikasikan). Yogyakarta : UIN Sunan Kalijaga

Kirkpatrick, D. (1994). Evaluating Training Programs - The Four Level. BerretKoehler Publisher.Inc.

Marwansyah. (2012) Manajemen Sumber Daya Manusia, Edisi Kedua. Alfabeta. Bandung.

Raco, J.R. (2010). Metode Penelitian Kualitatif: Jenis, Karakteristik, dan Keunggulannya. Jakarta : PT. Gramedia Widiasarana Indonesia. 